\title{
Diagnosis and Perspectives of Accounting in EU Countries
}

\author{
Laurentiu DINICA ${ }^{\star}$ Iuliana Oana MIHAI ${ }^{\star \star}$, Violeta Maria ISAI ${ }^{\star \star \star}$
}

\begin{tabular}{l}
\hline \multicolumn{1}{c}{ A R T I C L E I N F O } \\
\hline Article history: \\
Accepted June 2019 \\
Available online August 2019 \\
\hline JEL Classification \\
M41, M42 \\
Keywords: \\
Accounting, \\
Audit, \\
Harmonization \\
\hline
\end{tabular}

\begin{abstract}
A B S T R A C T
European Union, as you already know, is a framework for diversity. Furthermore, an exploratory point of view to trace the all 28 members of European Union in order to research all the accounting systems in place will be outdated due to harmonization attempts started in 2005. In these circumstances, it looks like more interesting to study, is the future of what will become the accounting science. Today, there is nothing than theories to predict the future of this field of science. After an exploratory digital search of all published literature regarding accounting as primary keyword, several conclusions, in our professional opinion, will be close enough, in the future decades.
\end{abstract}

(c) 2019 EAI. All rights reserved.

\section{Introduction}

E.U. as a relevant area and wide economic diversity of accounting systems, started with January $1^{\text {st }}$ of 2005, the process of enhancing the markets for European capital in order to increase competitiveness through homogeneous and widely recognized standards to adopt IAS/IFRS in order to publish financial statements including consolidated reports.

Cross-border trade and globalization of transactions demand new perspectives less influenced by Member State and their accounting traditions. From another point of view the requirement for a higher level of reliability concerning the financial accounting amounts become obvious. The harmonization process is to slow, so now in E.U. there are different accounting systems with increased cost of compliance and with reduced capabilities to compare the performance of economies within Member State, companies of each country and off course the entire E.U. economy in order to establish a solid base for decisions at national government or E.U. Council.

Alternative accounting system, with a fresh start, empowered by concentrated support from all players involved, developed for high level of national government and distributed to low levels of economy is actually a new direction to pursuit.

Starting with 2014, European System of Accounts ESA 2010, based on E.U. regulation, is now the single set of instructions, which provide an accounting framework, unique, continuous and uniform, in order to offer reliable information and an overview picture of financial position at all levels of Member State economy. Comparability, regularity and clearness of statements and reports on long-term perspective will provide reduced uncertainty and misrepresentation altogether with a more expressive picture of financial position and performance at all levels, economy, government, companies and, why not, to the level of households or single people.

Digital search revealed that the future of accounting is not a top subject and available contributions already published on this matter, in summary, has the character of theories. Relevant literature mentioned in references, a quite small number of cases, shows us that authors and professionals, still looking to the accounting science as a local implementation.

In conclusion of our introduction, a few assumptions occur in order to underline our professional judgment and we take in consideration reduced risks of new economic or financial crisis to influence the actual course of action in economy.

\section{Accounting harmonization will continue in slow motion}

It looks like a smart decision of E.U. to finally implement IFRS in order to publish financial consolidated statements as a first step to worldwide harmonization but still in opposition with the two 
principle of accounting used. These two methods, the cash accounting and the accrual accounting have the difference the moment in time when transactions are recorded.

When total value or just partial values are paid or received as part of transactions, this specific moment in time is the moment for recording in conformity with cash-based accounting. If we do not take into account the moment when the payment is done and we consider the specific moment in time when the transaction occurs as the moment for recording transactions we are in compliance with accruals based accounting.

Management of resources, standing of the macro level as general government factor of decision or at micro level as an economical entity, should be, at least, from the financial point of view, based in compliance with accruals accounting. Nevertheless, cash information is important, but still remain a detail in order to establish some specific point in time of transactions when changes have consequences.

Today, in many Member States, cash based accounting is very important and the repercussions of not having an objective and solid accruals accounting in order to offer financial reporting and transparent financial management may contain an increased quantity of risk that services are not delivered or decisions are made without knowing the cost and benefits.

We must have in mind that harmonization to a strong standard, in a long-term perspective, is imperative to ensure that the reported financial information still have the properties of reliable and credible information in order to be accepted by users and considered trustworthy. Nevertheless, harmonization to a unique standard will moderate temptations to influence information, in a positive or negative way, in order to hide difficulties.

Early identification of problems often means that the potential impact is reduced and the risks can be addressed to a new discovered vulnerability. In this moment, none of the European countries do not have accounting practices which can be characterized as complete accruals accounting. In many situations, Member States have mixed accounting systems, at the level of public sector and at level of private sector.

We do not found out official reports regarding countries reporting the actual status of accrual accounting implementation but after some observations we come to the conclusions that the following countries have mixed accounting systems: Austria, Cyprus, Denmark, Germany, Hungary, Ireland, Italy, Luxembourg, Portugal, Netherland and Slovenia.

Austria is the most advanced country in the implementation of the new accounting systems for the federal government on the basis of accrual accounting but for the counties and cities cash-based systems run. In oppositions, Cyprus, Ireland, Portugal, and the Netherlands, for this countries the general government use cash or modified cash accounting, in spite of local government that apply accruals accounting. In Cyprus accounting reform moving to accruals accounting do not overpass the planning phase, while in Ireland and Portugal is in progress for general government.

In Germany, the modernization of cash based system remain the primary focus of central and federal states but only a few states and some cities, have introduced real accruals accounting.

In Denmark accounting is mostly cash based but central government together with regional entities adopted the accruals accounting based systems.

In Luxembourg majority of entities use the cash based accounting but some kind of social funds adopt accruals accounting rules based on modified national accounting GAAP.

In Hungary, Romania and Slovenia, cash or modified cash accounting systems operate for all entities but in order to fulfill harmonization requirements some kind of modified accruals accounting is followed to publish financial statements.

Obviously we have heterogeneous results of our review and for certainty we do not have two Member States which apply the same accounting system or comply with the same standard. Moreover, is clearly for us that, different accounting rules are in force for different types of entities, which make E.U. to have the most complex accounting provisions.

In these circumstances, a real step forward in a due time is mostly unbelievable but on behalf of our review, small steps are made regularly.

\section{ESA 2010 will evolve in all directions}

ESA 2010 is the regulation which empower the principle that the statistics and, in generally, data reports should be based, as far as real time data are available, on direct source data. This is a courageous objective due to the fact that now is the common requirement for all Member States. As far as ESA 2010 is in force accruals accounting apply to all entities.

Member States should deliver all data in compact format and some verification processes consists of arithmetic and quality checks are in place supplementary plausibility and consistency checks are conducted by Member States as part of their compilation procedure.

Additionally, Eurostat carries out specific quality checks on the received data in order to validate the compilation but before publication checks are made on transmitted data and in case of problems redelivery of data is required. All of these consist in checking the internal arithmetical consistency of the national data the cross-referenced consistency with other data sets. 
The validation processes consists of arithmetic and quality checks in addition to the basic checks but are also made checks for plausibility concerning consolidation.

For the moment, the direct source data provider is represented by Government entities which are the only source of information but in time, due to improved channels of communication and large distribution of processes, the direct source of data will be household or single persons.

The information and communication system will be improved in all aspects, hardware and software, in order to link as many as possible direct sources and proceed to as many as possible checks in order to achieve higher consistency and data accuracy.

The compiling institutions will be extended and more professionals will understand the importance of ESA. Looking on long-term perspective, all entities, including the households, will be able to record transactions in compliance with ESA. A harmonization process will be effective and all entities will adopt ESA as accounting system and reporting system of financial statements.

The final evolving stage for ESA will be when even single people will record their own transaction as part of personal accounting and reporting tasks in order to underline added value to personal financial growth and taxes purposes.

Today, as part of ESA 2010, Romania have a specific institutional arrangement in order to fulfill all obligations. The Monetary and Financial Statistics Division of the National Bank of Romania's Statistics Department is responsible for producing the quarterly financial accounts of general government (QFAGG) and for the transmission of ESA Table 27 on QFAGG to Eurostat and the European Central Bank. NBR is independent from government authorities in exercising its powers, thereby guaranteeing, among other things, the absence of interference in respect to the compilation and dissemination of statistical information. On the over side, National Statistical System which is regulating the statistical system in Romania, in compliance with Law No. 226/2009, stipulates that, in the framework of the national statistical system, the National Bank of Romania is an independent producer of official statistics in its own area of competences, according to its own regulations, and is fully and independently in charge of developing statistical strategies and programs in the areas of competence according to its Statute.

However, in certain aspects, including sector delineation, classification of institutional units by sector and links between financial and non-financial accounts, there is close co-ordination with the National Institute of Statistics, which compiles the Romanian non-financial accounts, and the Ministry of Public Finance, which compiles general government debt statistics.

For government finance statistics purposes, there is in place the Protocol of cooperation between the Ministry of Public Finance (MOF), the National Institute of Statistics (NIS), the National Bank of Romania (NBR) and the National Commission of Prognosis (NCP) for the development of the National System for Government Finance Statistics. A working group, with members from the above-mentioned institutions, has been set up in order to discuss methodological issues and to answer questions raised by specific measures or transactions envisaged by the government. Regular meetings take place.

Each E.U. Member States have now the own institutional arrangements but in future perspective, extended arrangements taking in consideration regional development and management of resources, will take place.

\section{Artificial Intelligence as a support role}

The exponential spread of digital technologies and their impact on economic activities will transform the practice of accounting and as a consequence to professional accountants much more competencies will be required. Smart applications and systems will replace manual work and finally the Artificial Intelligence will support complex the increased regulation and stronger governance on the profession.

Knowledge of wider blockchain based software including distributed ledger will be the basics for all professional accountants. Skills consisting on use of analytics will enable more, better and closer real time reporting.

All accounting professionals will be expected to look beyond the numbers and make professional judgments in complementary work on datasets provided by AI (artificial intelligence). Humans will not be replaced by AI. Complementary roles will be in place and distributed tasks will make reporting of financial statements a team effort. RPA skills will be mandatory for each professional accountant.

Digital technologies will be so deep implemented that beyond AI as support in accounting the human cloud will be the next step of development.

\section{Audit as a tool for pushing forward}

As much as automation will be the heart of accounting system comparative with other systems, accounting will be always, at least, one step back. The need for regulation due to a high appetite for risk and profit will make the professional accountant to work in pair with audit professional.

Audit profession will be transformed by the changes will come and digital disruption will be one of them. Due to increased volumes of data to be analyzed, auditing the financial statements of global 
corporations will be the cyber challenge of the human kind. Various digital skills will be the next assets of auditors.

Audit standards will be based on ethics more than skills. Access to the profession will be made in two steps. First step as general audit professional and second step as corporate auditor.

Non-audit engagements will increase in volume and the image of audit profession will be changed in order to unify in one single profession all the specialized audit divisions.

Internal audit will be a continuous activity due to automation and external audit will be more often to short period of time.

Audit profession will be used as a tool to push for obtaining higher benefits and competitiveness from economic activities. Together with technological progress audit profession will produce a good impact in corporate life but we cannot see a wining end in fight against fraud. Still the manipulation of economic data will be a source of benefits in the future.

\section{Conclusions}

Our study, as empirical literature review, is for understanding the current status of the accounting in E.U. as system and to anticipate future development not only as a forecasting to the profession but also as new direction for future contribution in order to make reports of financial statements a valuable source of information in a cyber-world where information will be the new currency.

The accounting system, like ESA 2010, in the future will record all transactions in real-time but reports of financial statements will be published after validation. Accounting will incorporate more and more digital technologies and these technologies will be used for better analyze risks and fraud.

ERP systems will be so complex and will create so large volumes of data that sophisticated procedures and policies would not be enough without a higher education which will be focused on digital technologies.

To remain relevant and competitive as service the accounting profession will significantly evolve. The worse scenario for the professional accountants will be to accept electronic decision in order to ensure corporate safety and privacy.

However, annual financial statements will be replaced by new sophisticated reports and their importance in time will decrease. Real-time and complex dashboards will be available based on the records of the accounting system. All data will be protected and the access will be granted only for professional purposes.

Researchers will examine in a cross-referenced environment datasets selected through BI (Business Intelligence ) but still the forecasting of economic crisis will be difficult to predict. In real life everything will be counted in order to preserve the resources in other words everything will be accounting.

Meta-data will make information comparable in every field of science and, of course, accounting systems will evolve in this direction to create meta-data.

\section{Reference}

1. Alexander D. Truer and fairer. Uninvited comments an invited comments, EAR 3/96, London, 1996

2. Alexander D.,Archer S., European Accounting Guide, Harcourt Brace\& Company, New York, 1995

3. Anthony, R.N. (1983), Tell it like it was: a conceptual framework for financial accounting, USA: Richard D. Irwin Inc.

4. Baldwin-Morgan, A. 1993. The impact of expert system audit tools on auditing firms in the year 2001: A Delphi investigation. Journal of Information Systems 7 (1): 16-34.

5. Barro, R.J. 1990. macroeconomics 3rd ed. New York: Wiley.

6. Baumol, W.J. and A.S. Binder 1979 Economics: Principles and Policy. New York: Harcourt, Brace and Jovanovitch.

7. Bell, W. 1967. Technological forecasting-What it is and what it does. Management Review 56 (8): 64.

8. Berle, A.A. and G.C. Means. 1933. The Modern Corporation and Private Property. New York: Mac Millan.

9. Biondi, Y. A. 2008. "Schumpeter's economic theory and the dynamic accounting view of the firm: neglected pages from the Theory of Economic Development", Economy and Society, Vol. 27: pp 525-547.

10. Biondi, Y., A. Canziani, and T. Kirat (eds). 2007. The Firm as an Entity. Implications for Economics, Accounting and Law. New York and London: Routledge.

11. Bougen P.D., Vasquez D., Debating Spanish audit legislative: the audit laws of 1988, EAR 1/97, London, 1997

12. Bouma J.L. Feenstra D.W, Accounting and business economics traditions in the Netherlands, EAR 2/97, London 1997

13. Brown, R., 1905. A History of Accounting and Accountants, Edinbugh: T.C. \& E.C. Jack.

14. Brown. S., K. Lo, and T. Lys. 1999. Use of R2 in accounting research: Measuring changes in value relevance over the last four decades. Journal of Accounting \& Economics 28 (1): 83-115.

15. Busse von Colbe, Accounting and business connection traditions in Germany, EAR, 3/96, London, 1996

16. Cairns D., Applying International Accounting Standards, Butterworths, London, 1999

17. Cairns D., The future shape of harmonization: a replay, EAR 2/1997, London, 1997

18. Camfferman K, Netherlands, EAR 2/93, London, 1993

19. Caramanis C., The enigma of the Greek auditing profession: some preliminary results concerning the impact of liberalization on auditor behaviour, EAR 1/97, London, 1997

20. Cegielski, C. G. 2008. Toward the development of an interdisciplinary information assurance curriculum: Knowledge domains and skill sets required of information assurance professionals. Decision Sciences Journal of Innovative Education 6 (1): 29-49.

21. Chiang, R., and P. Venkatesh. 1988. Insider holdings and perceptions of information asymmetry: A note. The Journal of Finance 43 (4): 1041-1048.

22. Christiansen M., Denmark, EAR 2/93, London, 1993 Codification of Governmental Accounting and Financial Reporting Standards, third edition, Governmental Accounting Standards Board, Norwalk,1990. 
23. Combarros L.L., Accounting and financial audit harmonization in the European Union, EAR 4/00, London, 2000

24. De Jong, F.J. 1967. Dimensional Analysis for Economists. Amsterdam: North-Holland Publishing.

25. Debreu, G., 1959. Theory of value, New York: Wiley, 1959.

26. Dontoh, A., S. Radhakrishnan, and J. Ronen. 2004. The declining value relevance of accounting information and noninformation-based trading: An empirical analysis. Contemporary Accounting Research 21 (4): 795-812.

27. Drake, M. S., J. N. Myers, L. A. Myers, and M. D. Stuart. 2014. Short sellers and the informativeness of stock prices with respect to future earnings. Review of Accounting Studies (forthcoming).

28. Evans L.-, Nobes C., Harmonization relating to auditor independence: the Eighth Directive, the UK and Germany, EAR 3/98, London 1998

29. Feige P., How "uniform" is financial reporting in Germany?-The example of foreign currency translation, EAR 1/97, London, 1997

30. Finley, M. I., 1981, Economy and Society in Ancient Greece, New York: Viking press.

31. Fisher, I. 1906. The nature of Capital and Income London: MacMillan.

32. Flower J., The future shape of harmonization : the EU versus the IASC versus the SEC, EAR 2/97, London 1997

33. Francis, J., and K. Schipper. 1999. Have financial statements lost their relevance? Journal of Accounting Research 37 (2): $319-352$.

34. Halpern, J. Y. 2007. "Computer Science and Game Theory: A Brief Survey". http://www.cs.cornell.edu/home/halpern/papers/csgt.pdf

35. Hassik H.B.I, Mertens G, Quick R, Disciplinary practices an auditors in Europe: a comparison between Germany and Netherlands 3/98, London 1998

36. Holdsworth, Sir W. 1956. A history of English law.

37. Holstrum, G. L., T. J. Mock, and R. N. West. 1986. The Impact of Technological Events and Trends on Audit Evidence in the Year 2000: Phase I. Auditing Symposium VIII. Proceedings of the 1986 Touche Ross-University of Kansas Symposium on Auditing Problems, Lawrence, KS, 125-146.

38. Hopwood A., Some reflections on "The harmonization of accounting within the EU", EAR 2/94, London, 1994

39. Ijiri Y. 1967. The Foundations of Accounting Measurement. Englewood Cliffs, N.J.: Prentice-Hall.

40. Ijiri, Y. 1989. Momentum Accounting and Triple-Entry Bookkeeping. Studies in Accounting Research No. 31, American Accounting Association, Sarasota FL.

41. Ijiri. Y. 1995. "The Beauty of Double-Entry Bookkeeping and its Impact", in Martin Shubik, (ed.) Proceedings the Conference: Accounting and Economics in Honor of the 500th Anniversary of the publication of Luca Pacioli's Summa de Arithmetica, Geometria, Proportioni et Proportionalita. New York and London. Garland Publishing.

42. Inchausti B.G., The Spanish accounting framework: some comments, EAR 2/93, London, 1993

43. Inchausti G.B., Spain, EAR 2/93, London, 1993

44. Izutani, K., 1980, "The Origin of Double Entry Bookkeeping", Osaka Keidai Ronshu, 136: 1-34.

45. Jensen, W.H. and W.H. Meckling. 1976. "Theory of the Firm, Managerial Behavior, Agency Costs and Ownership Structure", Journal of Financial Economics, 3: 305-360.

46. Jonnson S., Accounting and business traditions in Sweden -a pragmatic view, EAR 3/96, London, 1996

47. Julve V.M., Accounting and Business Economics in Spain, EAR 3/98, London, 1998 Krzywda D., Bailey D.,

48. Klamer, A. 1989. "An accountant among economists: Conversation with Sir John R. Hicks", Journal of Economic Perspectives 3, Fall 1989, pp. 167-180.

49. Lev, B., and P. Zarowin. 1999. The boundaries of financial reporting and how to extend them. Journal of Accounting Research 31 (2): 353-386.

50. Littleton, A.C., 1933, Accounting Evolution to 1900, New York: American Institute Publishing Company.

51. Lombardi, D., R. Bloch, and M. Vasarhelyi. 2014. The future of audit. Journal of Information Systems and Technology Management 11 (1): 21-32. London, 1996

52. Mandl D., The new Austrian Financial Reporting Act, EAR 2/93, London, 1993

53. Martikainen T., Kallunki J.P., Perttunen J., Finnish earnings response coefficients: the information content of losses, EAR 1/97, London, 1997

54. Matessich R., Accounting as cultural force: past, present and future, EAR 2/1994, London, 1994

55. Međunarodni računovodstveni standardi 2000, HZRFD, Zagreb, 2000.

56. Mikol A., France, EAR 2/93, London, 1993

57. Minassion, Teresa, Parente-Pedro P, Martinez-Mendez, Pedro: "Setting up a Treasury in Economies in Transition", IMF, W/P, 1995

58. Napier J.C. Accounting and the absence of a business economics tradition in the United Kingdom, EAR 3/96, London,1996

59. Napier, C., UK, EAR 2/93, London, 1993

60. Nasi S, Finland, EAR 2/93, London 1993

61. Nasi S., Nasi J., Accounting and business economics traditions in Finland-from a practical discipline into a scientific subject and field of discipline, EAR 2/97, London, 1997

62. Naumann K.P., Financial reporting enforcement mechanisms as an element of corporate governance in Germany and reflection on their further development, EAR 4/00, London, 2000

63. Nioche J.P., Pesqueux Y., Accounting, economics and management in France: the slow emergence of an "accounting science", EAR 2/97, London 1997

64. Nobes C.W., Muller G.G., How "uniform" is financial reporting in Germany?: some replies, EAR 1/97, London 1997

65. Nowotny C., Gruber C., Austria, EAR 2/93, London, 1993

66. Olivier H., Challenges facing the accountancy profession, EAR 4/00, London, 2000 Ordelheide, D., True and fair view. A European and German perspective II, EAR 3/96, London, 1996

67. Premchard A.:"Public Expenditure Management", IMF, 1993.

68. Quick R., The legal liability of auditors in Germany, EAR 3/96, London, 1996

69. Radu, Riana Iren, and Angelica Stratulat. "New Aspects Regarding the Role of Banks in Economy in the Context of Globalization." Annals of the University Dunarea de Jos of Galati: Fascicle: XVII, Medicine 1 (2017).

70. Ramesh, K., and R. Thiagarajan. 1995. Inter-Temporal Decline in Earnings Response Coefficients. Working paper, Northwestern University.

71. Rowe, G., and G. Wright. 1999. The Delphi technique as a forecasting tool: Issues and analysis. International Journal of Forecasting 15 (4): 353-375

72. Schroeder M., Financial reporting by Polish listed companies for 1991, EAR 2/94, London, 1994

73. Sucher P.,Seal W., Zelenika I., True and fair in the Czech Republic: a note on local perceptions, EAR, 3/96, London 1996

74. Van der Plaats E., Regulating auditor independence, EAR 4/00, London, 2000

75. Van Hulle K., Harmonization of accounting standards in the EC: is it the beginning or is it the end? EAR 2/93, London, 1993

76. Vasarhelyi, M. A., and M. G. Alles. 2005. Continuous Monitoring and Assurance in a Real Time Economy. The Impact of European Integration on the National Economy. Proceedings of the International Conference of Business Information Systems, Babes-Bolyai University of Cluj-Napoca, Romania, October 28-29. 
77. Vasarhelyi, M. A., and M. Greenstein. 2003. Underlying principles of the electronization of business: A research agenda. International Journal of Accounting Information Systems 4: 1-25.

78. Vasarhelyi, M. A., M. G. Alles, and K. T. Williams. 2010. Continuous Assurance for the Now Economy. A Thought Leadership Paper for the Institute of Chartered Accountants in Australia. Available at: http://raw.rutgers.edu/docs/previousprojects/Continuous_Assurance_for_the_Now_Economy_-_2nd_draft\%20mav.pdf

79. Vergoossen R.G.A., The use and perceived importance of annual reports by investment analysts in the Netherlands, EAR 2/93, London 1993

80. Vigano E., Accounting and business economics traditions in Italy, EAR 3/98, London, 1998

81. Walton P., Company Law and accounting in nineteenth-century Europe, EAR 2/93, London, 1993

82. Weetman K.I, Clarkson A.H, Fraser M, Change and choice in Hungarian accounting practice. An exploratory study of the accounting law of 1991, EAR 3/96, London, 1996

83. Whittington G., Thorell P., The harmonization of accounting within the EU: problems, perspective and strategies, EAR 2/94, London, 1994

84. Worrell, J. L., P. M. Di Gangi, and A. A. Bush. 2013. Exploring the use of the Delphi method in accounting information systems research. International Journal of Accounting Information Systems 14 (3): 193-208.

85. Yamey B., Accounting in History EAR 2/94, London, 1994

86. Zambon S, Accounting and business economics traditions: a missing European connection?, EAR, 3/96,

87. Zambon S. Accounting and Business Economics Traditions, EAR, 3/96, London 1996.

88. Zambon S., Saccon C., Accounting change in Italy: fresh start or Gattopardo's revolution?, EAR 2/93, London 1993

89. Zan L., Towards a history of accounting histories: perspective from the Italian tradition, EAR, 2/94, London. 1994

90. Zeff S.A., International accounting principles and auditing standards, EAR 2/93,London,1993

91. *** IFAC - PSC: Occasional Paper 3 : Perspectives on Accrual Accounting, New York, 1997.

92. *** IFAC HANDBOOK, 2000. IFAC, New York, 2000.

93. *** Regulation on Budgetary Accounting and Plan of Accounts (Official Journal Narodne novine No.119/2001, 74/2002.) 